This is an author produced version of a paper published in Environmental Communication.

This paper has been peer-reviewed but may not include the final publisher proof-corrections or pagination.

Citation for the published paper:

Erica von Essen. (2017) Whose Discourse Is It Anyway? Understanding Resistance through the Rise of "Barstool Biology" in Nature Conservation. Environmental Communication. Volume: 11, Number: 4, pp 470-489. http://dx.doi.org/10.1080/17524032.2015.1042986.

Access to the published version may require journal subscription. Published with permission from: Taylor \& Francis.

Standard set statement from the publisher:

"This is an Accepted Manuscript of an article published in Environmental Communication on 10 Jun 2015, available online: http://www.tandfonline.com/10.1080/17524032.2015.1042986 ."

Epsilon Open Archive http://epsilon.slu.se 


\section{Whose Discourse is it Anyway? Understanding Resistance through the Rise of 'Barstool Biology' in Nature Conservation}

\section{Erica von Essen}

This study examines what happens when contentious lay citizens harness the technicalecological repertoire of experts as means of challenging nature conservation policy. The causes, manifestations and implications of this phenomenon are elucidated through a Critical Discourse Analysis. The case study is based on the wolf reintroduction project in Europe, with particular focus on Sweden, using illegal hunting discussions as a point of entry within the hunting community. It reveals the deployment of three topoi, which are defined as stock arguments situated within a discourse. Analysis shows how while some topoi often incur short-term gains in the debate because of their scientific guise, they are fundamentally relegated as folk science (or 'barstool biology') by government experts and, in some cases, contribute to the further marginalization of other knowledges. Acquiescence to this discourse is shown to greatly impede the debate. Finally, the study shows how lack of trust in the public dialogue, which hunters openly recognize to be colonized by ecological expertise, results in increasingly noncommunicative forms of resistance toward policy.

Keywords: resistance, illegal hunting, critical discourse analysis, species reintroduction, counterpublic, topoi

Erica von Essen is Ph.D. researcher, Environmental Communication Division, Department of Urban and Rural Development, Swedish University of Agricultural Sciences, Uppsala, Sweden. Correspondence to: Erica von Essen, Environmental Communication Division, Department of Urban and Rural Development, Swedish University of Agricultural Sciences, Inst för SOL, Miljökommunikation, Box 7012, Ulls väg 28 A, 75007 Uppsala, Sweden. Email: erica.von.essen@slu.se

\section{Introduction}

Resistance toward nature conservation policy, including crimes of dissent, may productively be construed as the result of particular pathologies that one can expose through rigorous inquiry. One line of inquiry has focused on the way in which citizens communicate in and about nature conservation processes, not least within this journal. Exploring the broader terrain of communication in these contexts has above all revealed the powerful and often 
excluding effect of the discourse that prevails at the science-policy interface (FeldpauschParker \& Peterson, 2014). Discourse is defined here as the practices of conversation, the collection of texts that are produced and the larger discursive context embodied in these texts (Putnam et al., 2005).

While the relative value that should be attributed to the advice of scientific experts compared to lay citizens remains the subject of debate (Linnell, 2013), reality reveals the surreptitious advancement of a scientific rationality in the discourses on contemporary nature conservation. Indeed, this rationality increasingly provides a direct and indirect basis for argumentation across diverse publics (Enders, 2009). In a critique of modernity, scientifically framed knowledge has achieved hegemony by becoming "the real game in town" (Haraway, 1988) insofar as it crowds out alternative knowledges, experiences and values that are based in lifeworld contexts. It is not uncommon to see this lived out through the de-legitimization of alternative discourses as emotionally driven or ill-informed (Buijis et al., 2014). On a conceptual level, the phenomenon has increasingly eventuated the subjugation of moral, aesthetic, cultural and ethical ways of knowing by scientific rationalism in the debate particularly on what natural resources and which wildlife should be conserved and why.

An implication of this phenomenon is, first, that the debate is 'frozen' at a level of technical-ecological reasoning (Arts et al., 2012) when it may be symptomatic of deeper problems and embedded in cultural tensions. Second, it has contributed to a fundamental power asymmetry between those groups unaccustomed to or disinterested in deploying such reasoning to resolve phenomena in their lives. This in turn has undermined the legitimacy and support for policy viewed as products of such a rationality or arrived at through such a 
discourse. Importantly, when policy is viewed with this scepticism, it frequently invites resistance by marginalized groups (Holmes, 2007).

With this paper, I want to observe the premise articulated by Barnes et al, (2003); namely, the ways dominant discourses construct experience and meanings, and prioritise forms of knowledge above others reveals not only the processes of exclusion but also the means of resistance. Indeed, scholarship has found that the dominance of expertise can propagate forms of counter-struggle by the marginalised in society (Foucault, 1991; Sovacool, 2009). Such resistance, in terms of its channels of communication, can broadly go two ways. First, resistance takes the form of acquiescence to and assimilation of the dominant discourse to the perceived tactical advantage of the group. Thus, I delineate what happens when recalcitrant hunters in Sweden embrace the technical-ecological discourse, using science as ammunition in their argumentation both toward experts and aimed at the broader public. Second, I show how the domination of the scientific rationality, technical repertoire and an ecological discourse - sometimes collectively termed environmentality (e.g. Darrier, 1999) has helped precipitate distrust and the radicalisation of marginalised hunters to the point of justifying illegal acts in resistance to wolf policy in particular (von Essen et al., 2014b).

It must be conceded that the scientific discourse, insofar as it can be conceptualised in environmental projects, is far from homogenous and can comprise multiple narratives and schools of thought (Stamou \& Paraskevopoulus, 2004). Some of these have been identified as greenspeak, survivalism, sustainable development, ecological modernisation, ecosystems services and ecospeak (Dryzek, 1997; Harré et al., 1999; Sumares \& Fidélis, 2011). For the purposes of this study, it is worth noting that scholars identify an increasing rhetorical and argumentative complexity characterizing discourses within the species reintroduction context 
(Arts et al., 2012), to which Swedish wolf conservation is counted. A Critical Discourse Analysis (CDA) of this phenomenon may therefore offer a productive path in illuminating the sub-discourse specific to species reintroduction projects, and which may be generalised for other such conservation contexts.

In this paper, a Critical Discourse Analysis is used to explore the manifestations of the surreptitious advancement of the technical-ecological discourse in nature conservation with respect to wolf reintroduction in Sweden. Wolf reintroduction and its impact on the livelihoods and lifestyles of rural residents is seen as a product of “...hegemonic and patronizing academic knowledge” by many hunters across Europe (Skogen et al., 2009, p. 4) and has constituted the object of vehement controversy and conflict in recent years (Arts et al., 2012). This is manifest in crimes of dissent, notably illegal hunting, in part to contest regulation and in part as a coping strategy that involves turning away from interference in what is seen as customary rural praxis (von Essen \& Allen, 2015).

The case study, which is mirrored by similar developments across Europe following the implementation of the Habitats Directive (e.g. Mischi, 2012; Pohja-Mykrä \& Kurki, 2014), offers an overview of the two ways in which citizens oppose reintroduction policy discursively and non-discursively respectively. I make this visible by extending the reach of the CDA with argumentation analysis, as advocated by Fairclough's revisited versions of CDA (Fairclough \& Fairclough, 2012). I hence borrow Classical Rhetorical Theory’s concept of topoi, meaning common ground arguments, to best understand the character of hunters' technical-ecological argumentation in relation to wolf reintroduction.

The contribution of this study to the field of communication is that it foregrounds turning of the elite's discursive weapons against them as a contemporary resistance practice, 
and critically discusses the unanticipated repercussions of this strategy. In so doing, the CDA joins the growing body of scholarship that apprehend citizens as more than recipients of scientific information in natural conservation, but as actors capable of critically engaging with expert knowledge (Fischer, 2000; Endres, 2009; Horsbøl, 2009). Namely, they can masterfully marshal technical-ecological jargon to their strategic benefit. Finally, I depart with the epistemic premise that although individual hunters may have internalised some narratives and now reproduce these unconsciously, there is significant intent on the part of hunters in their emulating of the hegemonic discourse as a generalised pattern of resistance. I highlight this by showing the strategy with which and the broader context in which it is deployed, which fundamentally suggest an oppositionality purposely directed toward wider publics in an ongoing debate (Brouwer, 2006).

The paper begins with a brief case description as to the socio-political and economic context of these hunters in relation to wolf conservation in Sweden, followed by a brief discussion of methods-After outlining the theoretical framework, a critical discourse analysis presents the topoi identified in the data. Finally, I discuss the macro context of these topoi and their implications on the wolf reintroduction conflict. In this section, I critically position this discursive resistance against increasingly non-discursive resistance practices to conclude the importance of understanding these two diverging paths.

\section{Case Study Context - The Return of Wolves}

In the Nordic countries, the EU Habitats Directive meant the return of the previously scarce or extinct wolf (Canis lupus) in the rural landscape. The impact of wolf populations on livelihoods and lifestyles quickly mobilised dissent, especially where the safety of domestic animals were 
concerned (von Essen et al., 2014b). This was particularly pronounced on the part of hunters and livestock farmers who experienced the prioritisation of elitist conservation goals over their lifeworlds. While a majority of Swedes favour the initiative, many of whom reside in urban areas, hunters view wolf conservation as a process that marginalizes the hunting community and, in many cases, has devastating effect on the countryside as a whole (Bisi \& Kurki, 2008, Sjölander-Lindqvist, 2009).

The conflict may prima facie be apprehended as stemming from rural-urban divides and class struggles (Krange \& Skogen, 2007). However, demographically, hunters are both urban and rural; some are working class and some are middle-class academics and all equally criticise expenditure on wolf management over economic investment in deteriorating rural industry (Sjölander-Lindqvist, 2009). Common to wolf sceptics is a perceived failure to make themselves heard and recognised as legitimate actors both in the public sphere and in decision-making processes on conservation issues, which are perceived to be colonized by an environmentalist agenda that leaves no room for alternative rationalities (von Essen et al., 2014b). Marginalization, therefore, is reinforced by economic and political disparities between hunters and 'pro-wolf' actors.

The perceived exclusion from the public debate on conservation issues led hunters to constitute a counterpublic comprised by these alternative interests and perspectives (von Essen et al., 2014b). Parallel to this alternative discursive arena, a growing phenomenon of illegal hunting of protected wolves testifies to the desperate situation and low legitimacy of the wolf conservation project (von Essen \& Allen, 2015). Present wolf mortality is estimated to be constituted one-third by illegal kills (Liberg et al., 2012). In effect, already at this juncture one 
can discern dual resistance and coping strategies in response to the injustice of the situation around wolf conservation: the deployment of discourses of resistance and political activities of the counterpublic on the one hand, and the 'shoot, shovel and shut up' of wolf kills on the other.

Recognising that neither resistance tactic was sufficient in granting hunters authenticity as political citizens capable of deliberating on conservation issues, indeed in many ways stigmatizing hunters in modernity as blood-thirsty thrill-killers, as backward rural hillbillies and as anti-environmentalists (Sjölander-Lindqvist et al., 2010; Ekengren, 2012; Mischi, 2008; 2013), Swedish hunters can be understood as having embarked on a different discursive strategy that involves challenging expert knowledge on its own turf.

\section{Method}

Acquiescence to the technical-ecological discourse was revealed through a two-stage Critical Discourse Analysis conducted from the two leading daily newspapers in Sweden, Svenska Dagbladet and Dagens Nyheter, the print magazine Svensk Jakt by the Swedish Hunting Association, and the websites of the Swedish Hunting Association and the Hunters' National Association. These websites comprised articles, letters to the editor, staff blogs and members' comments in response to articles. This selection captures, first, the broad national debate and, second, the formal and informal discourse within the hunting community.

The input search term in the discourse analysis was 'illegal hunting' and its eight synonyms in Swedish, which comprise terms similar to 'unlawful', 'non-legal' and 'poaching' (von Essen et al., 2014a). The focus on illegal hunting rather than 'wolf conservation' or 'wildlife management' had a twofold rationale: first, it serves as a boundary for the preponderance of 
articles devoted to the reintroduction project; second, it allows us to discern the link between power, discourse and resistance articulated by Barnes et al. (2003). A guiding premise to this inquiry is thereby that illegal hunting can be taken as a form of resistance toward the regulatory regime (von Essen et al., 2014a), around which discussions on management practices may be simultaneously expressed in a given position on the killing of wolves. The years for the search were 2001-2014 to reflect the inciting debate around illegal wolf hunting in Sweden.

The search took place in two steps. First, the print media were surveyed to discern common themes that expressed elements of a technical-ecological discourse. The search for illegal hunting yielded a total of 313 articles from the daily newspapers and 87 articles from Svensk Jakt. A total of 96 articles from the daily newspaper selection were discarded on the basis of pertaining to global poaching trends. Findings from the remaining articles were abstracted into four preliminary themes that were the most frequently occurring touchpaper for the technicalecological discourse as it appeared in conjunction with reports on the illegal hunting of wolves in particular. These were, in order of frequency:

(1) Favourable conservation status

(2) Culling practices

(3) Biodiversity management and

(4) Wolf unnaturalness/hybridity

In the next step, these four themes were used as search terms for the websites of the Swedish Hunting Association and Hunters' National Association. Following the more inductive search 
process of the print media, the subsequent website search purposely looked for argumentation that either (1) contested or conveyed scepticism to present management practices and regulation around wolves, and (2) which used ecological, biological or genetic criteria (or reference to scientific authority having used these) as support for this position. Through this two-stage inquiry, two of the themes were subsequently altered to more accurately reflect the findings from the texts in the hunting community. Namely, culling practices subsumed biodiversity conservation and collectively comprised what was deemed to be a 'proactive management' argument at its core. More than 120 text sources featured in this stage of the analysis.

$\begin{array}{cc}\text { Source } & \text { Amoun } \\ \text { News items } & 18 \\ \text { Articles } & 21 \\ \text { Editorials } & 8 \\ \text { Blog entries } & 7 \\ \text { Comments } & 70+\end{array}$

Table 1: Text sources from the hunting websites

In terms of representativeness of this sample, it is important to state that because the Swedish Hunting Association is partly reliant on government funding for its operations, some hunters have conjectured that they may be more constrained in what can be published on this 
controversial topic. Indeed, their perceived 'softer line' toward wolf reintroduction have constituted a point of criticism among the more contentious factions of hunters (Cederqvist, 2013). In search for less official texts, the search was expanded to include the blog portal of the Swedish Hunting Association, which hosts the blogs (and editorials) by four leading staff members. These four blogs are public and professional in character as its web articles, but have somewhat greater leeway in what can be published.

From the plurality of thematic constructs of text available in environmental discourse analyses (including accounts, framing, rhetoric, social representations, interpretative repertoires, narratives, storylines, transcripts and spheres of argument, e.g. Goodnight, 1982; Figari \& Skogen, 2011; Zeyer \& Roth, 2011; Bixler, 2013), I suggest that in this context it is most helpful to understand these themes as topoi, as borrowed from Critical Rhetorical Theory. Topoi are storehouses of arguments, stock formulas from which argumentation can be cast by providing related ideas and supportive ideas (Bizzell \& Herzberg, 2001) Topoi draws from the word places, or 'commonplaces', which can be said to denote the common ground by which one delivers an argument in a debate, or, the 'seat on which rhetoric arguments are placed' (Barker et al., 2013). The identified themes constitute topoi in this setting by commonly occurring as tropes across nature conservation debates.

A robust CDA will make visible not just how topoi feature as resistance in this context, but why they have hardened in the debate. I attempt this by following Fairclough's (1989) approach to CDA by considering the micro-level (what is actually being said), the meso-level (the context of production and reception of texts) and the macro level (the societal context). Importantly, CDA has matured in Fairclough's later work through a marriage with argumentation analysis 
that allows for a version that is more compatible with Habermas' theory of communicative action (Fairclough \& Fairclough, 2012). This amelioration of CDA provides clearer normative critique in evaluating the discursive predicament in terms of its fulfilment of democratic virtues, including deliberative fairness and legitimacy. Following Chourlaki and Fairclough’s (1999) adaptation of Bernstein's definition of recontextualization of discourse, recent CDAs have also increasingly focussed on the relocation, appropriation and colonization of discourses from one context to another. This may be fruitfully observed here, in the appropriation of technicalecological discourse by hunters and, somewhat more problematically, the simultaneous colonization of the entire debate by this rationality.

By drawing from critical theory and Habermas' theory of communicative action (TCA) (1984), I discuss the implications of this colonization in terms of a loss in democracy, legitimacy and sustainability on the part of the regulatory regime. In so doing, the CDA offers a critical yet hopeful examination of power in nature conservation, and thereby sets the premises for more democratic and constructive ways for debating in nature conservation conflicts.

\section{The Rise and Role of Science in Modernity}

In modernity, so-called grand narratives equate truth, reason and progress with science and technology (Lyotard, 1979). Healey (1992) writes that contemporary public planning is rooted in this context. But the power of science and rationality has revealed itself to function as means of control in increasingly totalitarian systems. A corollary of this is that society has decoupled in the form of a system and a lifeworld. The former is dominated by an instrumental rationality and technical reason and is encroaching on the lifeworld in modernity (Habermas, 1984). The 
lifeworld is seen as a lived domain, comprised by communicative rationality and informal, intersubjective and culturally grounded understandings essential to furnish legitimacy.

A dilemma that faces public policy is, first and intuitively, that technical-scientific knowledge is insufficient to resolve political, social or ethical dilemmas (Endres, 2009). But the criticism cuts further into the very premises of science itself, in which answers and truths of science change in time and space and become obsolete. Scholars have shown how they instead have become the manufacture of uncertainty, risk and scenarios to be avoided (Giddens, 1990; Beck, 1992). Briefly stated, maintaining the supremacy of science when defining the future can be said to compromise the fundamental role of alternative worldviews and rationalities that are grounded in the intersubjective meanings of the lifeworld (Feyerabend, 1988).

Scholarly consensus suggests that modernity is a sufficiently distinct epoch in terms of discourse to merit particular theorization (Chouliaraki \& Fairclough, 1999). For the critical theorists cited above, normative critique on modernity has heretofore centred on how we bring back values of the moral, ethical and aesthetic into planning our future. Gradually, the request for the integration of values and a broader span of perspectives has entered the domain of public policy legislative requests for more public participation within natural resource management. Indeed, this has been explicitly articulated in species reintroduction projects, with the European Commission indicating the value in integrating diverse knowledge forms behind policy (Linnell, 2013). While unarguably the pragmatic thing to do to appease the public this may also be seen as an attempt to promote a communicative rationality among interest groups. The latter refers to the expansion of reason from scientific empiricism to comprise all ways of knowing (Healey, 1992). This can be viewed as shifting the debate from the technical to the public sphere (Sovacool, 
2009). This shift is held as particularly important given that wildlife may be thought of as public resources or, beyond this, as commons.

\section{How science empowers discourse}

Through TCA, I have now outlined the implications of grand narratives colonizing the lifeworld. What, then, is inveigling about these narratives, and what empowers them? A critical mass of scholars inspired by Foucault have highlighted that unpacking discourses can make visible relations of power (Schiappa, 1989; Foucault, 1991; Dryzek, 2005; Usher, 2013). Within this it has been discovered that dominant discourses achieve success inter alia because of their ability to “...clothe, disguise, rarefy and wrap [themselves] systematically in the language of truth, discipline, rationality, utilitarian value and knowledge." (Said, 1983, p. 216). As symbolic producers of truth narratives, those who deploy this discourse may go on to mold hegemonic cultural forms, thereby constituting a powerful form of domination in modernity (Thompson, 1991). Indeed, in natural resource management praxis, the hegemony of ecological argumentation is currently undermining the legitimacy of dialogue as a democratic project (Hajer \& Versteg, 2006; Sovacool, 2009; Zeyer \& Roth, 2011).

In terms of resulting power dynamics in nature conservation, scholarly debate within the field of environmental communication has revealed two things: first, a valuable strategy for recalcitrant actors when engaging with publics is to "...cloak themselves in the language of environmentalism" (Hajer \& Versteeg, 2006, p. 180). This imitation has for example been observed in the appropriation of the construct of sustainable development by various interest groups in the past decades (Dryzek, 1997). Second, the debate has revealed that pre-emptively shoring up scientific rhetoric is infectious and often causes opponents to do the same (Besel, 
2012). This has been observed, in what I contend is the most valuable parallel outside of the environmental context, through scientific creationism and its success in emulating the hegemonic discourse of scientific theory. Moral and theological objections hence became disguised in idioms of scientific respectability (Toumey, 1991) and periodically garnered traction in policy, even to the point of being taught in schools. Ultimately, however, scientific creationism is derogatorily dismissed as 'pseudo-science' distinct from the technical literature by using its form and jargon, but without its rigorous methodological requirements (Toumey, 1991).

There are inevitable distinctions between critical theory's take on modernity and Foucault's understanding of discourses that need to be harmonized before the conclusion of this theoretical chapter. First and most notably, the critical theorist's pursuit for communicative rationality is premised on the assumption that citizens are capable of reaching intersubjective agreement (Philipps, 1996). In a critique of Habermas’ TCA, Foucault contended that the former disregarded the influence of various power discourses on the formation of the pre-political individual. Thus, while Habermas sees the constructive and emancipatory capacity of dialogue, Foucault argues, first, that any dialogue occurs between citizens who have already been touched - and in some ways compromised - by power structures.

Habermas later conceded that the identity of the individual constitutes a complex object that is heavily informed by the dominant narrative in society. This offers a bridge from Foucault's complexity of the discourse of power to critical theory's grand narratives of truths as defined by science, technology and logic uncoupled from communicative reason. At the same time, in contrast to Foucault, I wish to argue that liberating the premises for discussion by normatively empowering a breadth of life-world perspectives can go a long way toward reducing 
the influence of hegemonic discourses in these contexts. This assertion can be said to build practically on the ideas of Critical Discourse Analysis (Fairclough, 2012), which seeks to provide progressive social change and emancipatory knowledge through the uncovering of power relations and inequalities as they are reproduced and expressed in discourses.

\section{Critical Discourse Analysis of Topoi}

The critical discourse analysis revealed that a central topos under contention that is strategically harnessed by hunters is that of the (self-) contradiction of scientific calculations (Horsbøl, 2011), taking the form of contestations on the ecologically determined favorable conservation status for wolves ('GYBS'). Lack of precise objectives from the EU level and the ability of national selfdetermination as to the numbers of large carnivore populations have positioned the 'viability' of species as a critical weapon in the arsenal of ecological experts. Hunters both addressed the contradictions in different calculations, which Horsbøl (2011) terms a meta-communicative element criticizing conditions for discussing rather than the substantive issues, and advanced expert calculations of their own as the true and accurate models. For example, hunters made selective use of credentialed scientists whose accounts support their positions ${ }^{1}$, such as Olof Liberg, in part to reappraise the term in relation to the calculation for minimum viable population (MVP).

When discussing the contradiction of GYBS, argumentation most frequently centered on the following: references to scientific authority with calculations of MVP that modeled population dynamics data with stressing events and demographic analyses and which were considerably lower than the public figure from the Swedish Environmental Protection Agency;

\footnotetext{
${ }^{1}$ Indeed, said experts have accused wolf skeptics of misappropriating the science for their own benefit. See for example: Chapron, G (2014). Challenge the abuse of science in setting policy. Nature 516, 289 (18 December 2014 )
} 
the discrediting of perceived 'pro-wolf/conservationists' estimates on account of their political and consequent tainted, unscientific nature; reference to the particular ecological system of Sweden and consequent inability to extrapolate positive trophic cascade effects from wolf conservation in Yellowstone where wolves had been successfully restored as apex predator; the improving genetic diversity of the wolf packs as a result of Finnish-Russian immigrant wolves and consequent need for tempering the figure for GYBS (which factored in the poor genetic status of Swedish wolves). A significant portion of texts pushed for more objective science behind calculations.

The second topos pertained to culling wolf populations to positive effect. In this line of argumentation, references were made to scientific authority where one had determined that active management benefits wildlife. Hunters drew parallels to forestry benefitting from human industry, and select wildlife species thriving as a result of agricultural practices. The process of slowing population growth as means of providing more time for wolves to adapt to their reappearance also surfaced. The active management of the environment was extrapolated both to wolf and game management, where hunters' articles extolled the health of animal populations when exerted to human hunting pressures, citing for example coyote management through extensive culling in the U.S. Hunters also cited the European Charter on Hunting and Biodiversity as a scientific authority legitimating the role of hunting in relation to the powerful buzzword 'biodiversity' in current technical-ecological jargon. They promulgated the view of culling as a balanced, interactive, technical and healthily competitive relationship with carnivores in contrast to strict protection and the present use of ecologically 'non-viable' nonlethal measures, such as relocating wolves by helicopter, which was framed as an artificial intrusion into the balance of the ecosystem. 
As an extension of this, a significant number of accounts from editorials, articles and comments centered on painting a picture of a countryside increasingly bereft of human activity and grazing by livestock and wildlife owing to the increasing wolf population. It was held that in the years during which the wolf was absent in the landscape, “...biodiversity thrived across the ecosystem through our management because of the grazing of open pastures and meadows by wildlife," which was predicated on the negative effect of allegedly wolf-induced afforestation on biodiversity-rich fields. Additional technical-ecological arguments for the topos of proactive culling of the wolf population connected to the need to instill a 'natural' fear of humans in wolves and reclaim their consequent natural and wild social behavior, which was argued had been lost when the wolf received protected status upon recolonisation. This topos thereby called to a familiar stewardship role of humans toward the environment (“man as manager”), highlighting both obligations and benefits to managing the environment in a sustainable way lest it fall to chaos. This can be taken as a direct opposition to the ideas of rewilding, which are commonly seen to underpin carnivore reintroductions in Europe (von Essen et al., 2015).

The third and final topos pertained to wolf genetic impurity and hybridity. Having put forward ecological criteria to challenge the wolf as a viable species, genetic and morphological argumentation also appeared in the articles and blog entries. Indeed, one constructed the wolf as an impure and unnatural wolf-dog hybrid whose place in the landscape could simply be challenged on the basis of objective biomorphological criteria, such as skull shape, coat colour and texture, claw composition, paw size and ear shape. Along this axis of argumentation were charges of its unnatural behaviour of territoriality, predation and unsuitability to the wild, including the livestock targeting tendencies ascribed to the hybrid. This was connected to a potential danger of food-conditioned carnivores. "Shepherd-wolf”, “wolf mutt”, "mid-Swedish 
forest dog" and "doggy" were used to delegitimise wolves as their pure, wild forms in conjunction with several illegal-hunting discussions.

Several commentators on the website of the National Hunters Association articulated the need for an improved, comprehensive genetic testing of the wolf in conjunction with international researchers. One stated how he "...would be willing to commit large parts of [his] income on independent DNA testing of wolves.” Arguments for the licensed or reinstated hunting of wolves also made references to cleansing the population of these genetically impure wolves to render the remaining packs more viable for GYBS (which could thus be lowered). The hybridity argument, which can be said to centre on a 'natural/genetically pure' topos that is commonly deployed in environmental issues so as to provide a justificatory scope for eliminating unnatural elements in the landscape (Horsbøl, 2011; Siipi, 2011) was also raised in conjunction with the need to instil the natural fear of humans in wolves, predicated on the understanding that hybrids were tame enough to approach human settlements. Although hybrid is a misnomer, the topos has come to constitute a powerful narrative in some hunting circles, and has interestingly surfaced in other parts of the world where wolves and species purity is concerned (e.g. Nowak \& Federooff, 1998; Skogen et al., 2009; Theodorakea, 2014).

As testament to this, in Finland, the hunting lobby's harnessing of the natural/genetically pure topos has succeeded in exempting hunters from charges if DNA analysis reveals that the illegally killed wolf did not conform to a genetically pure conception of Canis lupus. A troubling legal loophole for killings, it may be noted that articles discussing the topic of wolf hybridity were somewhat scarce on the Swedish Hunting Association, while more frequent on the Hunters' National Association. This may be a reflection of the fact that it is a topos that is not 
unequivocally accepted by hunters as holding weight or mattering in the grand scheme in the debate.

\section{Context of topoi}

Website comments served as the primary proxy for the context of reception to these texts. These blog and article comments demonstrated additional acquiescence to the technical-ecologic discourse identified through the three topoi. In one particularly striking case of delegitimation of the opposing side, 'balcony biologists' was deployed by commentators to undermine the argumentative authority of conservationists. With balcony biologist is implied that this group of conflated persons - urban residents, animal rights activists, environmentalist NGOs inter alia are inferior biologists to the 'real' scientists by virtue of being disconnected from the environment that they study. The topos has been identified in other wolf management debates in Europe, with Theodorakea (2014) finding rural breeders purporting how they were "more ecologists than the ecologists", thereby using ecology as the yardstick of competence and authority.

The validation of the technical-ecological discourse as the masterframe to which arguments defer (Elling, 2010) has also been uncovered by other scholars on the institutional level of hunters. The Swedish Hunting Association stated that they are “...not so good at emotional

arguments that affect opinions. We deal with facts instead." (Ekengren, 2012). This statement negatively ascribes the use of emotional and manipulative rhetoric calling to subjective imaginaries in a thinly veiled jab at animal rights activists. In so doing, they validate the 
hegemony of science by differentiating themselves from the inferiority of soft, subjective and emotional arguments by contending they 'deal with facts', akin to the implied inferiority of urban balcony biologists.

It must be noted that the wolf reintroduction project cannot yet be myopically rendered as solely fuelled by a technical-ecological discourse. This is rather one, albeit an especially fast increasing, discursive tract within species reintroduction that the search process was purposely designed to make visible. But in these projects, problems cannot easily be rendered in purely material, let alone ecological terms. On the contrary, the wolf reintroduction conflict is inextricably embedded in broader issues and structures pertaining to rural depopulation, socioeconomic inequality, change and outsiders, and class-based struggles (Linnell, 2013; Krange \& Skogen, 2007). Indeed, these issues often feature in rhetoric on injustices. Hunters within the counterpublic contend they lack the tools and language to be heard, that one must frame arguments in a certain way, and that the regime privileges the ecological discourse, a phenomenon commonly observed in natural resource management (Clausen et al., 2010), and particularly within Natura 2000 (Buijs et al., 2014).

As a corollary of this, the very establishment of the hunting counterpublic in Sweden may be seen as a necessary response to the present inequality of public debate, granting hunters authenticity as citizens in an alternative public that is not colonized by scientific expertise. Articles furthermore revealed how wildlife management retains strong ties to situated life-world knowledge developed over generations and through embodied experiences of the countryside. However, the devaluing of this life-world knowledge in the economy of argumentation within nature conservation has gradually pushed the purer ecological discourse to the surface, drowning 
out potentially dangerous, soft and unscientific words like 'tradition', 'stewardship' and 'rural expertise’.

In 1982, Goodnight wrote that it was arguments grounded in personal experience, not science, which possessed the greatest currency in policy through perpetuating an '... aura of false intimacy' (p. 225). This may still hold true in some contexts and to a lesser extent in species reintroductions. One can perhaps assert that both the scientific and the personal spheres of argumentation are steadily eroding the public sphere (Sovacool, 2009), where the epistemic product is a more inclusive and co-constructed social knowledge. This is evidenced in wolf reintroduction by the fact that alongside the dominance of an ecological parlance, other rhetoric continues to be selectively prioritized depending on the discursive opportunity structure of the given communication context (Usher, 2013). This is typically done through the discursive interconnection of the technical-ecological discourse as nexus with normative narratives on for example community, family, injustice, cultural continuity and aestheticism (Sandberg \& Foster, 2005).

An example of this was the discussions on the alleged dangerousness of the wolf. This was based on both reference to historical precedent and to biological attributes, including parasitology where the wolf was contended to potentially spread Echinococcus sp or rabies, and biological reasons for the wolf's ferocity and subsequent incommensurability to human settlements. Yet, as noted, discussions also comprised subjective calls to safety and feelings of fear. While it may be anticipated that these attempts would be synergistically successful on account of interweaving multiple spheres of arguments to support its position, Robbins (2006) found that in wildlife management, ecological experts tend to dismiss the narratives that call to 
fear and safety as a discourse of 'hysterical housewives'. This discrediting, akin to hunters' 'balcony biologists', brazenly confers hegemony to an objective ecology.

The implications of the phenomenon on a societal level

The implications of this rationality problematic can be said to be threefold. First, it is epistemically problematic by narrowing down the ways in which we can arrive at the truth. A society that is dominantly reliant on one type of discourse and rationality is vulnerable to impacts on this discourse. At the same time, these impacts are inevitable and intuitive as technoscience is based on historical specificity and new scientific evidence, and its assertions and innovations are thus contestable as 'truths' (Haraway, 1988; Beck, 1992). Thus, preoccupation with wolf genetic hybridity or calculations of GYBS impoverishes our common repertoire and makes us vulnerable to shifts in thinking, such as contentions that GYBS was previously miscalculated by failing to include the now 'critically important' factor x/algorithm.

Second, the development is democratically problematic. The diverse settings for the debate fail to become democratic by submitting to preset premises of discourse. Even if these represent premises that one has chosen for oneself as means of challenging policy, the choice has not necessarily been taken under free conditions. Disguising arguments as ecological truth claims, moreover, often lends itself to an instrumental approach to democracy whereby participants deploy powerful arguments not to reach a common goal but to persuade others with rhetoric (Dingler, 2005; Alexander, 2008). Crucially, this is done through deploying knowledge whose rhetorical power lies in its declaration that is non-rhetorical and non-political (Schiappa, 1989). 
Scholars within the field of environmental communication have additionally related belief in science to a de facto lowering of the need for involvement in decision-making (FeldpauschParker \& Peterson, 2014), which unveils a direct threat to democracy. Beyond this, I wish to emphasize that the development has implications on the construct of a hunting counterpublic as enumerated above. The counterpublic was established by hunters as an alternate arena and political reaction to the exclusionary premises and discourse of the public. But as Philipps (1996) writes, “... recognising alternative publics is not enough if they are to be subjected to the decision rules of the rationality that they may well have been formed to challenge..." (p. 242). Thus the counter in counterpublic is abrogated by virtue of opposing only the material goals of the dominant public, while embracing its premises for argumentation.

Third, ecology has in this context become less a tool for informing the way we see the world and more a resource for appropriation between interest groups. The deployment of ecological tropes and rote arguments of ecological dynamics means the privileging of the interests of those who are able to mobilize it, whilst rendering the arguments of those who cannot as ‘subjective’ or 'lay' (Zeyer \& Roth, 2011). Moreover, adoption of the ecological discourse is fundamentally problematic for hunters; as is often the case their ecology is dismissed as strategic and unscientific (as 'barstool biology', Robbins, 2006) by the state or other interest groups, or ultimately disproved by scientists. Should hunters succeed in advancing a technical-ecological topos, as is the case for Finnish courts concerning the now-excused killing of hybrid wolves, they have incurred material gains at the expense of submitting to the colonization of public debate by scientific rationality. They have thereby unwittingly displaced alternative rationalities farther from the public debate. 


\section{The demise of discursive communication}

So far, I have argued that the homogenization of discourse in the debate challenges the legitimacy of policy. What the current situation in Swedish wolf reintroduction indicates is that with a public dominated by technical-ecological expertise, leaving no place for alternative formulations, communication will increasingly seek to bypass the rigid parameters for argumentation by proceeding in alternate channels. What, then, are these alternative channels, and why is the development worrisome? It is the retreat from the public arena to private and counterpublic spheres in society, where attitudes undergo radicalization as feelings of injustice are magnified (von Essen et al., 2014b).

In Sweden, as in the other Nordic countries pursuant of the Habitats Directive on wolf reintroduction the rejection of the dominant premises of the public is evidenced most powerfully by the range of non-discursive communicative crimes of dissent now practiced toward policy. These include civil disobedience, boycotts, road blockades, rallies and political initiatives (von Essen \& Allen, 2015). On the other, less communicative end, stands the illegal killing of wolves. It is, of course, multifunctional and may be undertaken without motives of resistance (von Essen et al., 2014a). Yet here it necessarily denotes a strategy that is more on the hunters' terms, while it marks a conduit of resistance that effectively entails turning one's back on society. Furthermore, the practice is problematic to resolve as communicative, given that the message is not conveyed directly but risks distortion and misinterpretation along the way (von Essen \& Allen, 2015). The acts are equally problematic to resolve as appeals to a public conception of justice akin to civil disobedience, given that using harm toward animals as means to deliberative ends falls outside the parameters of reasonable disagreement on a conception of justice under the 
current ethos. In the case of illegal hunting, such practices rather invite criminalization of hunters and their stigmatization by the rest of society.

What then are some potential ways forward in thorny situations like these? Given what I have argued to be a great complexity and embeddedness of species reintroduction conflicts, an approach is needed that will unveil underlying differences and grievances rather than the obfuscation that results from equating them to technical-ecological terms. Topoi are malleable entities in theory, but the problem here is that they have become hardened through certain communication practices. By parity of reasoning, then, alternative communication practices may serve to increase reflexivity, broaden interpretative repertoires, and allow us to go beyond topoi and in so doing bring back and empower moral, ethical and aesthetic values in the public debate.

It might be questioned whether moral and aesthetic arguments may likewise harden as topoi to freeze the debate. As identified by the alternative rhetoric of hunters, 'family safety' may in some ways constitute a topos to be invoked in nature conservation. While toposification of such tropes may result from bringing back alternative rationalities into the debate, their broadening of the discursive arena is normatively desirable. This is, first, because permitting the entry of alternative spheres of argumentation will generate a more imaginative and mutually constructive planning process not restricted to the participation of those equipped to wield the technicalecological discourse. Second, the three topoi identified in this paper are pathological because they are presented as evident truths when they are actually based on competing scientific interpretations of diverging normativity, such as contesting calculations on favorable conservation status and discrepant views on the benefits and drawbacks to a proactive management of the environment. What moral and ethical argumentation can bring to the table is 
to make visible this normativity and thereby bring back honesty and responsibility into how we plan our future.

How these fora should be designed, calls for more research. A point of entry may be the creation of alternative public platforms that invite a more communicative rationality among participants by engaging them beyond the technical-ecological and the private spheres. Research should thus not shy away from experimental, action-oriented approaches that harness the social imagination and whole-life engagement of actors beyond the confines of entrenched topoi. Future Creating Workshops (see, for example, Nielsen \& Nielsen, 2006) may be one such approach that builds on the emancipatory knowledge extolled by critical theory and is consistent with the aims of critical discourse analysis.

\section{Conclusion}

This paper examined the rise of hegemonic discourse in environmental projects. Using the case study of wolf reintroduction in Sweden, it explored an emerging technical-ecological discourse and its implications on the conflict, democracy and sustainability. This was illuminated through adapting a recent version of Fairclough's CDA that accommodated normative critique from Habermas' theory of communicative action and encouraged the utilization of argumentation analysis within the CDA. Three main topoi of this discourse were identified as circulating arguments in the hunting community. These included contested calculations of favorable conservation status, active ecosystem management, and wolf genetic impurity. In line with Fairclough’s (1989) premises for critical discourse analysis, I outlined the micro-level of the text,

including the content and meaning of the topoi, the meso-level context that included the species 
reintroduction conflict, and, finally the macro-level, where I related the phenomenon to a dilemma of modernity.

'Environmentality' extends far beyond the scope of hunters using ecological topoi. It was shown to be connected to a broader dilemma of modernity, of how to combine science with lifeworld rationalities without the former colonizing the latter. The considerable challenge of addressing this development particularly in controversial species reintroductions is thus in need of alternative communication practices characterized by a degree of open-endedness and social imagination beyond narrowly defined scientific parameters. Viewed less abstractly, the paper recognized that citizens in the debate need to be brought back from private and technical arenas into a public platform of communication.

Acknowledgements: I wish to thank Dr. Hans Peter Hansen and Professor Tarla R. Peterson for their guidance and valuable feedback on critical theory and critical discourse analysis respectively. This research was funded by the Swedish Research Council Formas [grant numbers 2012-7896-23062-36].

\section{References}

Alexander, E. R. (2008). Framing discourse on the environment: A critical discourse approach. London. Routledge. 
Arts, K., Fischer, A., \& van der Wal, R. (2012), Common stories of reintroduction: A discourse analysis of documents supporting animal reintroductions to Scotland. Land Use Policy, 29, 911920

Barker, J., Gilmore, S., \& Gilson, C. (2013). Rhetorical profiling: Modes of meaning generation in organizational topoi. Canadian Journal of Administrative Sciences, 30, (4), 280-291,

Barnes, M. Newman, J. Knops, A., \& Sullivan, H. (2003). Constituting 'the public' in public participation. Public Administration. 81 (2), 379-399

Beck, U. (1992) Risk society: Towards a new modernity. New Delhi: Sage

Besel, R. (2012). Prolepsis and the environmental rhetoric of congressional politics: Defeating the Climate Stewardship Act of 2003. Environmental Communication, 6 (2), 233-249

Bisi, J., \& Kurki. S. (2008). The wolf debate in Finland: Expectations and objectives for the management of the wolf population at regional and national level. Seinäjoki, University of Helsinki.

Bixler, 2013. The political ecology of local environmental narratives: Power, knowledge, and mountain caribou conservation. Journal of Political Ecology, 20, 273-285 
Bizzell, P., \& Herzberg, B. (2001). General introduction. The rhetorical tradition: readings from classical times to the present. 2nd edition. St Martins: Bedford.

Brouwer, D. C. (2006). Communication as counterpublic. In G. J. Shepherd, J. St. John, \& T. Striphas (Eds.), Communication as...: Perspectives on theory (pp.195-208). Thousand Oaks: Sage Publications.

Buijs, A.m Mattijssen, T., \& Arts, B. (2014). The man, the administration and the counterdiscourse: an analysis of the sudden turn in Dutch nature conservation policy. Land Use Policy, $38,676-684$

Cederqvist, K.O. (2013). Förbundet har tappat 25000 medlemmar. Dagbladet. Published 2013$03-13$

Chouliaraki, L., Fairclough, N. (1999). Discourse in late modernity: Rethinking critical discourse analysis. Edinburgh: Edinburgh University Press

Clausen, L.T., Hansen, H. P., \& Tind, E. (2010). Democracy and sustainability: A lesson learned from modern nature conservation. In Nielsen, K.A. Elling, B. Figueroa, M., \& Jelsøe, E. (Eds.), A new agenda for sustainability (pp. 229-248). Surrey, England: Ashgate.

Darrier, E. (1999) Foucault and the environment: An introduction. In Darier, E. (Ed.), Discourses of the environment (pp. 1-34). Malden, Mass: Blackwell Publishers. 1-34. 
Dingler, J. (2005). The discursive nature of nature: Towards a post-modern concept of nature. Journal of Environmental Policy \& Planning, 7 (3), 209-225

Dryzek, J (1997). The politics of the earth: Environmental discourses. Oxford: Oxford University.

Ekengren, A.M. (2012). The wolf debate and political cleavages: Interest mobilisation in Sweden. Statsvetenskaplig Tidskrift, 114 (4).

Elling, B. (2010). Rationality and the environment: Decision-making in environmental politics and assessment. London: Routledge.

Endres, D. (2009). Science and public participation: An analysis of public scientific argument in the Yucca Mountain controversy. Environmental Communication, 3 (1), 49-75

Fairclough, N. (1989). Language and power. London: Longman.

Fairclough, N., \& Fairclough, I. (2012). Analysis and evaluation of argumentation in critical discourse analysis: Deliberation and the dialectic of enlightenment. Argumentation et Analyse du Discours, 9 (2), 1-27. 
Feldpausch-Parker, A. M., \& Peterson, T.R. (2014). Communicating the Science behind Carbon Sequestration: A Case Study of US Department of Energy and Regional Partnership Websites. Environmental Communication: 1-20. doi: 10.1080/17524032.2014.955039.

Fischer, F. (2000). Citizens, experts and the environment: The politics of local knowledge. Durham, NC. Duke University Press.

Figari, H., \& Skogen, K., 2011. Social representations of the wolf. Acta Sociol. 54, 317-332.

Foucault, M. (1991). Discipline and punish: The birth of a prison. London: Penguin.

Giddens, A. (1990). The consequences of modernity. Cambridge: Polity Press.

Goodnight, G.T. (1982). The personal, technical, and public spheres of argument. Journal of the American Forensics Association, 18, 214-227.

Habermas, J. (1962). The structural transformation of the public sphere: An inquiry into a category of bourgeois society. Translated by Burger, T., \& Lawrence, F. Cambridge: Polity Press

Hajer, M., \& Versteeg, W. (2005). A decade of discourse analysis of environmental politics: Achievements, challenges, perspectives. Journal of Environmental Policy \& Planning. Special Issue: Does discourse matter? Discourse, power and institutions in the sustainability transition, 7 (3), $175-184$ 
Haraway, D. (1988). Situated knowledges: The science question in feminism and the privilege of partial perspective. Feminist Studies, 14(3), 575-599.

Harré, R., Brockmeier, J., \& Mühlhäusler, P. (1999) Greenspeak. A study of environmental discourse. London \& New York: Sage.

Healey, P. (1992). Planning through debate: The communicative turn in planning theory. The Town Planning Review, 63 (2), 143-162

Holmes, G. (2007). Protection, politics and protest: Understanding resistance to conservation. Conservation and Society, 5, (2), 184-201.

Horsbøl, A. (2011). Responding to expert arguments: Emerging lay topoi in focus group interviews on GM Crops. In van Haaften, T., Jansen, H., de Jong, J., \& de Koetsenruijter (Eds.), Bending opinion: Essays on persuasion in the public domain, Leiden: Leiden University Press. (395-406)

Krange, O., \& Skogen, K. (2007). Reflexive tradition: Young working-class hunters between wolves and modernity. Young, 15 (3), 215-233. doi: 10.1177/110330880701500301.

Krange, O., \& Skogen, K. (2011). When the lads go hunting: The 'hammertown mechanism' and the conflict over wolves in Norway. Ethnography, 12 (4), 466-489. 
Liberg, O., Chapron, G.,Wabakken, P., Pedersen, H.C., Thompson, H., \& Sand, H. (2012). Shoot, shovel and shut up: Cryptic poaching slows restoration of a large carnivore in Europe. Proc Biol Sci, 279 (1730), 910-915.

Linnell, J.D. (2013). From conflict to co-existence: Insights from multi-disciplinary research into the relationship between people, large carnivores and institutions. European Commission.

Lyotard, J. F. (1979). The postmodern condition: A report on knowledge. Manchester: Manchester University Press.

Mischi, J. (2008). Les militants ouvriers de la chasse. Éléments sur le rapport des classes populaires au politique. Politix, 83 (3), 133-153

Mischi, J. (2013). Contested rural activities: Class, politics, and shooting in the French countryside. Ethnography, 14, 64-84

Negt, O., \& Kluge, A. (1972). Public sphere and experience: Toward an analysis of the bourgeois public sphere. Theory and History of Literature, vol. 85. University of Minnesota Press

Nielsen, K.A., \& Nielsen, N.S. (2006). Methodologies in action research: Action research and critical theory. In Nielsen, K. A. \& Svensson, L.G (Eds.), Action research and interactive research: Beyond practice and theory (pp. 63-87). Maastricht : Shaker Publishing. 
Nowak, R.M., \& Federoff, N.E. (1998). Validity of the red wolf: Response to Roy et al. Conservation Biology, 12 (3), 722-725. doi: 10.2307/2387257.

Philipps, K. R. (1996). The spaces of public discussion. Reconsidering the public sphere. Communication Monographs, 63, 231-248

Putnam, L., Grant, D. Michelson, G., \& Cutcher, L. (2005). Discourse and resistance: Targets, practices and consequences. Management Communication Quarterly, 19 (1), 5-18

Robbins, P. (2006). The politics of barstool biology: Environmental knowledge and power in greater Northern Yellowstone. Geoforum , 37 (2), 185-199

Said, E. (1983). The world, the text, and the critic. Cambridge, MA. Harvard University Press

Sandberg, A., \& Foster, J. (2005). Challenging lawn and order: Environmental politics of lawn care reform in Canada. Environmental Politics. 14(4), 478-494.

Schiappa, E. (1989). Spheres of argument as topoi for the critical study of power/knowledge. In Gronbeck, B. (ed) Spheres of argument (pp. 47-56). Annandale, VA: Speech Communication Association. 
Siipi, H. (2011). Non-backward-looking naturalness as an environmental value. Ethics, Policy, Environment. 14, 329-344

Sjölander-Lindqvist, A. (2009). Social-natural landscape reorganized: Swedish forest-edge farmers and wolf recovery. Journal of Conservation and Society, 7 (2), 130-140.

Sjölander-Lindqvist, A., Karlsson, M., \& Cinque, S. (2010). Att jaga varg: En studie av 2010 års licensjakt i Sverige. Report for Center for Public Sector Research. Gothenberg University

Skogen, K., Mauz, I., \& Krange, O. (2009). Cry wolf! Narratives of wolf recovery in France and Norway. Rural Sociology, 73 (1), 105-133

Sovacool, B. (2008). Spheres of argument concerning oil exploration in the Arctic National Wildlife Refuge: A crisis of environmental rhetoric? Environmental Communication, 2 (3), 340361.

Stamou, A., \& Paraskevopoulos, S. (2004). Images of nature by tourism and environmentalist discourses in visitors books: A critical discourse analysis of ecotourism. Discourse \& Society, 15 (1), $105-129$

Sumares, D., \& Fidélis, A. (2011). Natura 2000 and the narrative nature of nature: A case for critical discourse analysis. Journal of Integrative Environmental Sciences, 8 (1), 53-68 
Theodorakea, I. (2014). Who let the wolves out? Perceptions about the presence of the Wolf in Central Greece. Swedish University of Agricultural Sciences, Masters thesis. http://stud.epsilon.slu.se/6957/

Toumey, C. (1991). Modern creationism and scientific authority. Social Studies of Science, 21 (4), 681-699

Usher, M. (2013). Defending and transcending local identity through environmental discourse. Environmental Politics, 22 (2), 811-831

von Essen, E., Hansen, H.P., Nordström Källström, H., Peterson, M.N., \& Peterson, T.R. 2014a. Deconstructing the poaching phenomenon: A review of typologies for understanding illegal hunting. British Journal of Criminology, 54 (4), 632-651.

von Essen, E., Hansen, H.P., Nordström Källström, H., Peterson, M.N., \& Peterson, T.R. (2014b). The radicalisation of rural resistance: How hunting counterpublics in the Nordic countries contribute to illegal hunting. Journal of Rural Studies. doi: http://dx.doi.org/10.1016/j.jrurstud.2014.11.001.

von Essen, E., \& Allen, M.P. (2015). Reconsidering illegal hunting as a crime of dissent: Implication for justice and deliberative uptake. Criminal Law \& Philosophy, 1-16. doi: 10.1007/s11572-014-9364-8. 
von Essen, E., Hansen, H.P., Nordström Källström, H., Peterson, M.N., \& Peterson, T.R. (2015). Toward a critical and interdisciplinary understanding of illegal hunting: a synthesis of research workshop findings. Urban and Rural Reports 2015:1. Swedish University of Agricultural Sciences (1-39)

Zeyer, A., \& Roth, W.M. (2013). Post-ecological discourse in the making. Public Understanding of Science, 22, 33-48 